\title{
Otizmin Basılı Medyada Temsili: Ulusal Eylem Planından Sonraki Sürecin İncelenmesi
}

Representation of Autism in Printed Media: Investigation of the Process after the National Action Plan

\author{
Sinem KARS ${ }^{1}$, Gökçen AKYÜREK ${ }^{2}$ \\ ${ }_{1}^{1}$ Uz. Erg., Hacettepe Üniversitesi, Sağlık Bilimleri Fakültesi, Ergoterapi Bölümü, Ankara, Türkiye \\ ${ }^{2}$ Dr. Öğr. Üyesi, Hacettepe Üniversitesi, Sağlık Bilimleri Fakültesi, Ergoterapi Bölümü, Ankara, Türkiye
}

\section{öz}

\begin{abstract}
Amaç: Türkiye'de otizmin görülme sıklığı artmaktadır. Görülme sıklığındaki artış, otizm konusundaki farkındalığı ve otizmli bireylere yönelik hizmetleri önemli bir hale getirmektedir. Farkındalığın artırılması ve otizmli bireylere yönelik hizmetlerin geliştirilebilmesi için medyanın kullanımı önemlidir. Medya, toplumun bir konudaki farkındalığını geliştirmede ve devlet politikası ile topluma sunulan hizmetlerin tanıtımında etkin bir role sahiptir. Bu nedenle, bu çalışmada Otizm Spektrum Bozukluğu Olan Bireylere Yönelik Ulusal Eylem Planı'ndan sonraki süreçte otizm ile ilgili haber içeriklerinin incelenmesi amaçlanmıştır. Gereç ve Yöntem: Çalışma kapsamında günlük olarak yayınlanan, yüksek satış rakamına sahip ve farklı görüşleri temsil ettiğine inanılan üç gazete incelendi. 3 Aralık 2016-12 Şubat 2018 tarihleri arasında "otizm", "otistik" ve "otizmli" anahtar kelimeleri ile tarama yapıldı. Bu haberlerin incelenmesinde içerik analizi uygulandı. Kategorileştirme aşamasında öncelikle haber başlıkları, spotları ve haber metinleri bir arada değerlendirildi. Değerlendirme sonucunda, haberler kategorilere ayrıldı. Sonuçlar: Otizmle ilgili çıkan toplam haber sayısının 45 olduğu tespit edildi. Değerlendirme sonucunda, eğitim, bilinçlendirme/farkındalık, sosyal katıım, spor ve sanat ve sağık başlıkları elde edildi. Tartışma: Otizmle ile ilgili haberlerin az olduğu tespit edilmiştir. Otizm ile ilgili toplumda farkındalık oluşturulması için medyanın yeteri kadar kullanılmadığı düşünülmektedir. Haber sayısındaki azlığın sebebi sonraki çalışmalarda incelenebilir.
\end{abstract}

Anahtar Kelimeler: Otistik bozukluk; Haberler; Gazeteler; Politika

\section{ABSTRACT}

Purpose: The incidence of autism spectrum disorders is increasing in Turkey. Therefore, the awareness of society about autism and services for autistic individuals is important. The use of the media is important for raising awareness and improving services for autistic individuals. The media has an effective role in promoting public awareness of the community and publicity of public policy and public services. For this reason, in this study, it is aimed to examine news contents related to autism after the National Action Plan for Individuals with Autism Spectrum Disorder. Material and Methods: Three newspapers published daily, with high sales figures and believed to represent different opinions were examined. Between December 3, 2016 and February 2, 2018, the keywords "autism", "autistic" and "autism" were traced. Content analysis was applied to these reports. During the categorization phase, news headlines, spots and news texts were evaluated together. As a result of the evaluation, the news was divided into categories. Results: It was determined that the total number of news articles about autism is fourty-five. As a result of the evaluation, training, awareness / awareness, social participation, sports and arts and health titles were obtained. Conclusion: There are few news about autism. It is thought that the media is not used enough to create awareness in the society related to autism. The reason for the lack of news can be examined in subsequent studies.

Keywords: Autistic disorder; News; Newsletters; Policy

Sorumlu Yazar (Corresponding Author): Sinem KARS E-mail: snmkrs@hotmail.com ORCID ID: 0000-0001-8774-2602

Geliş Tarihi (Received): 08.08.2018; Kabul Tarihi (Accepted): 20.11.2019

Bu çalışma, 2-5 Mayıs 2018 tarihleri arasında Akdeniz Üniversitesi (Antalya)'nde gerçekleştirilen V. International Eurasian Educational Research Congress / EJER Congress 2018'de sözel bildiri olarak sunulmuştur 
Otizm Spektrum Bozukluğu (OSB), "Üç yaşından önce başlayan, sosyal etkileşim ve iletişimde önemli ölçüde bozulma ve anormal gelişim, ilgi ve etkinliklerin belirgin sınırlılı̆ı gibi özelliklerle kendini gösteren gelişimsel bir sendrom" olarak tanımlanmaktadır (Amerikan Psikiyatri Birliği, 1995). Türkiye'de ve dünyada otizmin görülme sıklığı artmaktadır (Yosunkaya, 2013). OSB'li bireylerin başta eğitim olmak üzere, sağlık, mesleki eğitim, istihdam gibi alanlarda sosyal katılımlarında engeller bulunmaktadır. OSB'li bireylerin sosyal katılımı, biriylerin iyilik haliyle yakından ilişkilidir (Orsmond, Shattuck, Cooper, Sterzing ve Anderson, 2013). Sosyal katılımdaki engellerin, iyilik hali üzerindeki olumsuz etkilerine ek olarak, OSB'li bireylerin ailelerinin yaşam kalitelerinde azalma olduğu da bildirilmektedir (Lee, Harrington, Louie ve Newschaffer, 2008). OSB'li bireylerin diş tedavilerinin zorlu olduğu, buna karşın ağız ve diş sağlığı hizmetlerine erişemedikleri için diş kayıplarının meydana geldiği (Fahlvik-Planefeldt ve Herrstrom, 2001) belirtilmektedir. Ayrıca, beslenme sırasında beş çeşit yiyeceğe kadar sınırı yiyecek yedikleri, dolayısıyla ciddi sağlık problemleri yaşadıkları bildirilmektedir (Cermak, Curtin ve Bandini, 2010). Diğer taraftan, özellikle zorunlu eğitim çağındaki OSB'li çocuk sayısının 16.837 olduğu göz önüne alındığında, OSB'li çocukların eğitimleri önemli olmaktadır (Otizm Spektrum Bozukluğu Olan Bireylere Yönelik Ulusal Eylem Planı, 2016). Bu eğitimlerin erken çocukluk döneminden başlayarak, ilkokul ve ortaokul eğitimini de kapsayan okul dönemi ve yetişkinlik dönemindeki iş ve mesleki eğitim programları da dâhil olmak üzere yaşam boyu süren ve nitelikli olması önemlidir (Aydın ve Özgen, 2018; Köse, Özbaran, Yazgan ve ark, 2017). Dolayısıyla OSB'li bireylerin ve ailelerinin sosyal katıımlarını artırmak, iyilik hallerini desteklemek için sosyal politikaların geliştirilmesi ve uygulanması gerekmektedir.

Aile ve Sosyal Politikalar Bakanlığı'ın "Engellilerin ve yaşlıların toplumsal hayata etkin biçimde katılmalarını sağlamak üzere; engellilere ve yaşılıara yönelik sosyal hizmet faaliyetlerini yürütmek", "Korunmaya, bakıma ve yardıma muhtaç birey ve aileleri tespit etmek, desteklemek ve gerekli hizmetlerden yararlanmasını sağlamak", "Birey ve ailelere yönelik eğitsel faaliyet ve projeler yürütmek, konferans, seminer ve benzeri etkinlikler düzenlemek; kültür ve sanat faaliyetlerini gerçekleştirmek" ve "Alan taramasında elde edilen bilgileri değerlendirmek ve bunları ilgili diğer uygulayıcı kurum ve kuruluşlara da aktararak hizmetlerin geliştirilmesine ve yeni hizmet modellerinin oluşturulmasına yardımcı olmak" görevleri gereği engelli bireylerin yaşam alanlarında karşılaştığı sorunlara yönelik temel hak ve hizmetlere ilişkin yasal düzenlemelerle birlikte, özellikle OSB'li bireylere yönelik spesifik çalışmalar yapılmaya başlanmıştır. Bu kapsamda, Aile ve Sosyal Politikalar Bakanlığı, "Otizm Spektrum Bozukluğu Olan Bireylere Yönelik Ulusal Eylem Planı"nı hazırlamıştır. Hazırlanan bu plan 3 Aralık 2016 tarih ve 29907 sayılı Resmi Gazetede yayınlanmıştır. Bu planla, "Toplumun tüm kesimlerinin OSB konusunda farkındalık düzeyinin artırıması ile OSB olan bireylere yönelik sağlık, eğitim ve destek hizmetlerinin sürekliliğinin sağlanması için kurumlar arası işbirliğinin güçlendirilmesinin amaçlandığı" belirtilmektedir (Otizm Spektrum Bozukluğu Olan Bireylere Yönelik Ulusal Eylem Planı, 2016).

Belirtilen amaçlara ulaşılabilmesi için medyanın kullanımı önemlidir. Medyanın toplumu değiştirme doğrultusundaki etkileri "değiştirip dönüştürme", "önemsiz değişiklikler yapma" ve "kuvvetlendirme" olmak üzere 3 ana kategori içinde toplanmaktadır (Boyd-Barrett ve Braham, 2013). Bu nedenle yayınlanan eylem planının ardından medyadaki OSB'li çocuklarla ilgili yapılan haberlerin önemli olacağı öngörülmektedir. Çalışmamızda bu planın yayınlanmasından sonra, ulusal medyada yer alan otizm ile ilgili haberlerin içeriklerinin incelenmesi amaçlanmıştır.

\section{GEREÇ VE YÖNTEM}

Çalışma kapsamında günlük olarak yayınlanan, yüksek satış rakamına sahip ve farklı görüşleri temsil ettiğine inanılan üç gazete incelendi. Çalışma için gazeteler seçilirken gazetelerin (a) yüksek tiraj sayısına sahip olmalarına, (b) farklı sahipli yapıda olmalarına, (c) farklı yayın politikalarına sahip olmalarına dikkat edildi (Altuntaş ve Altınova, 2015). $\mathrm{Bu}$ gazetelerin Cumhuriyet, Hürriyet ve Radikal gazetesi olmasına karar verildi. Çalışma kapsamında ilgili gazetelerde 3 Aralık 2016-12 Şubat 2018 tarihleri arasında "otizm", "otistik" ve "otizmli" anahtar kelimeleri ile tarama yapıldı. Aynı haberler araştırmaya dahil edilmedi. Araştırmada ekler de tarama kapsamına alındı. Bu amaçla (1) OSB'li çocuklar hangi sıklıkla yer almıştır? (2) Haberlerde OSB'li çocuklarla ilgili ana konular nelerdir? sorularına yanıt arandı. Her bir gazetede anahtar kelimelerin geçtiği haberler kategorilere göre ayrıldı ve bu kategorilerde kaç haber olduğu sayıldı. Daha sonra haberlerin içeriklerine ve sunumlarına bakıldı. 


\section{Istatistiksel Analiz}

Otizmin konu olduğu haberler niteliksel veri olarak değerlendirildi. Niteliksel verilerin analizinin "veri ile çalışma", "verileri organize etme", "belli gruplara ayırma", "örüntüleri araştırma", "önemli noktaları belirleme" ve "bunlara dayalı olarak söyleneceklere karar verme"yi içerdiği bildirilmektedir (Bogdan ve Biklen, 1998).

Anahtar kelimeler ile tarama yapıldıktan sonra 80 adet habere ulaşıldı; bu haberlerden aynı içeriğe sahip olan haberler değerlendirme dışı bırakıldı. Değerlendirmeye toplam 45 haber alındı. Bu haberlerin incelenmesinde içerik analizi yapıldı. Kategorileştirme aşamasında öncelikle haber başlıkları, spotları ve haber metinleri bir arada değerlendirilerek aşağıdaki başlıklarda kategoriler oluşturuldu: (1) Eğitim, (2) Bilinçlendirme/farkındalık, (3) Sosyal katıım, (4) Spor ve sanat, (5) Sağlık. Elde edilen sayısal veriler yüzdelik şeklinde sunuldu. Haberlerin otizm spektrum bozukluğu ile ilişkisi göz önünde bulundurularak; OSB ile ilgili haberler içerik analizi yöntemi kullanılarak analiz edildi. Ayrıca içerik analizi ile belirlenmiş haber teması örneklerinin daha iyi açıklanabilmesi amacıyla, temaların analizi incelenen haberler içerisinden seçilmiş örnek haber metinleri ile desteklendi ve zenginleştirildi. Böylece haber metinlerinde OSB ile ilgili temaların ipuçlarının ortaya konulması amaçlandı.

\section{SONUÇLAR}

OSB'li çocuklarla ilgili haberler incelendiğinde yaklaşık olarak 45 habere rastlanmıştır; bu durum OSB'li bireylere yazılı medyada çok fazla yer verilmediğini göstermektedir. Haberlerin içerikleri incelendiğinde; \%34'ünün eğitimle; \%23'ünün bilinçlendirme/farkındalıkla; \%19'unun sosyal katılımla; \%16'sının spor ve sanatla; \%8'inin ise sağıkla ilgili olduğu tespit edilmiştir.

Eğitimle ilgili spor kulüplerinin OSB'li çocuklara verdikleri hippoterapi hizmeti, üniversite öğrencilerinin OSB'li çocukların eğitimlerine destek olmak için proje hazırlamaları, OSB'li çocuklar için geliştirilen cep telefonu uygulamaları ve açılan eğitim merkezleri gibi haberler yer almaktadır (Yıldız, 2016; Anonim, 2017a; Anonim, 2017ı; Anonim, 2017h; Dörtkardeş, 2017; Kumanovalı, 2017; Özbalı, 2017; Anonim, 2018) (Görsel 1).

Sosyal katılımla ilgili otizmli çocuklara ve/veya ailelerine yönelik paraşütle atlama, gezi, korunaklı iş yerlerinde çalışmalarına destek olma, OSB'li çocuklar için düzenlenen konserler gibi haberler bulunmaktadır (Anonim, 2017b; Anonim, 2017g; Ekin, 2017) (Görsel 2).

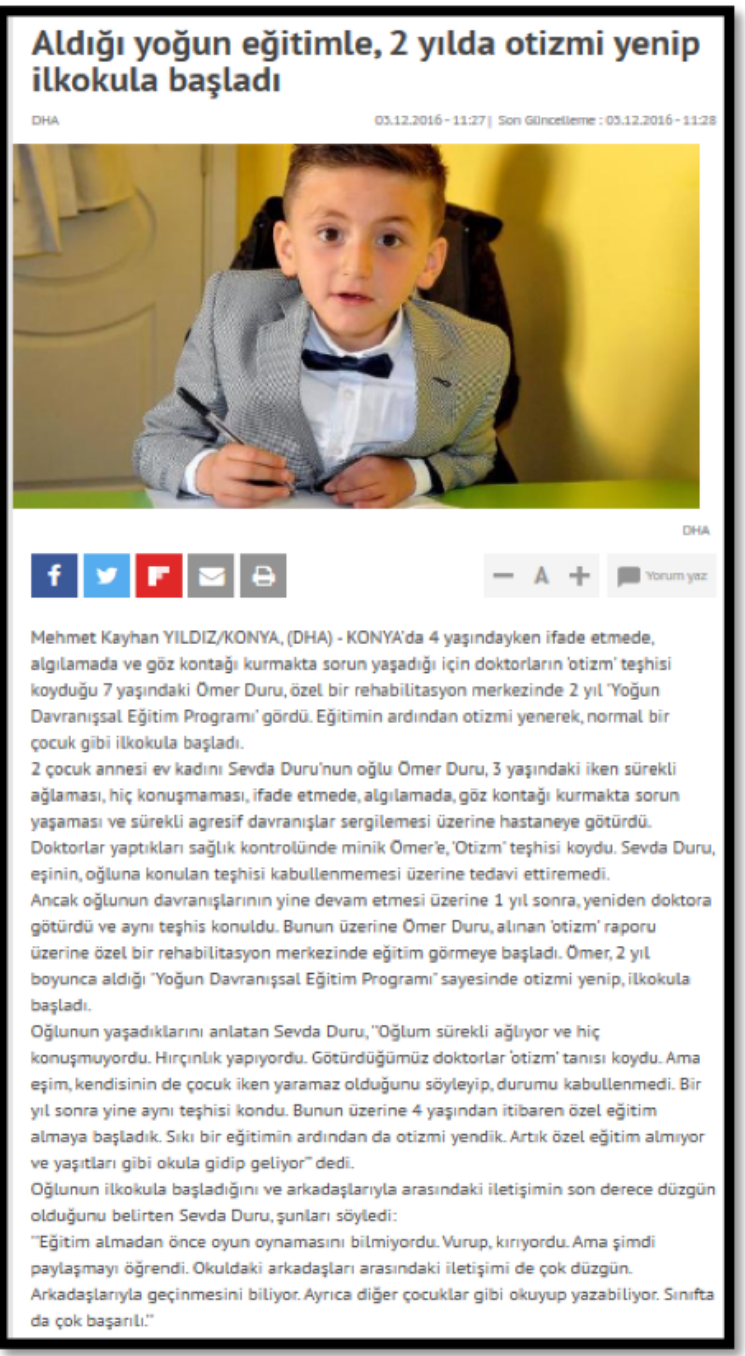

Görsel 1. Eğitimle ilgili haber örneği.

Bilinçlendirme/farkındalık ile ilgili otizmin ne olduğu, erken tanı ve tedavi hakkında aileleri bilgilendirme gibi toplumun otizm konusunda bilgilenmesini amaçlayan haberler yer almaktadır (Atalay, 2016; Anonim, 2017c; Anonim, 2017d; Atalay, 2017; Bahçetepe, 2017b; Arman, 2018; Öndeş, 2018) (Görsel 3).

Spor/sanatla ilgili otizmli çocukların güzel sanatlara olan ilgilerine vurgu yapılarak başarı göstermiş olan otizmli çocuklardan bahsedilmektedir (Anonim, 2017e; Anonim, 2017f; Ipek, 2017) (Görsel 4).

Sağlıkla ilgili OSB'li çocukların özellikle ağız ve diş sağlığııın önemine vurgu yapılmaktadır (Özel, 2017). Ayrıca, duyu bütünleme tedavisi, GAPS diyeti gibi OSB'li çocuklara yönelik tedavi yöntemlerine değinilmektedir (Bahçetepe, 2017a; Özgenç, 2017) (Görsel 5). 


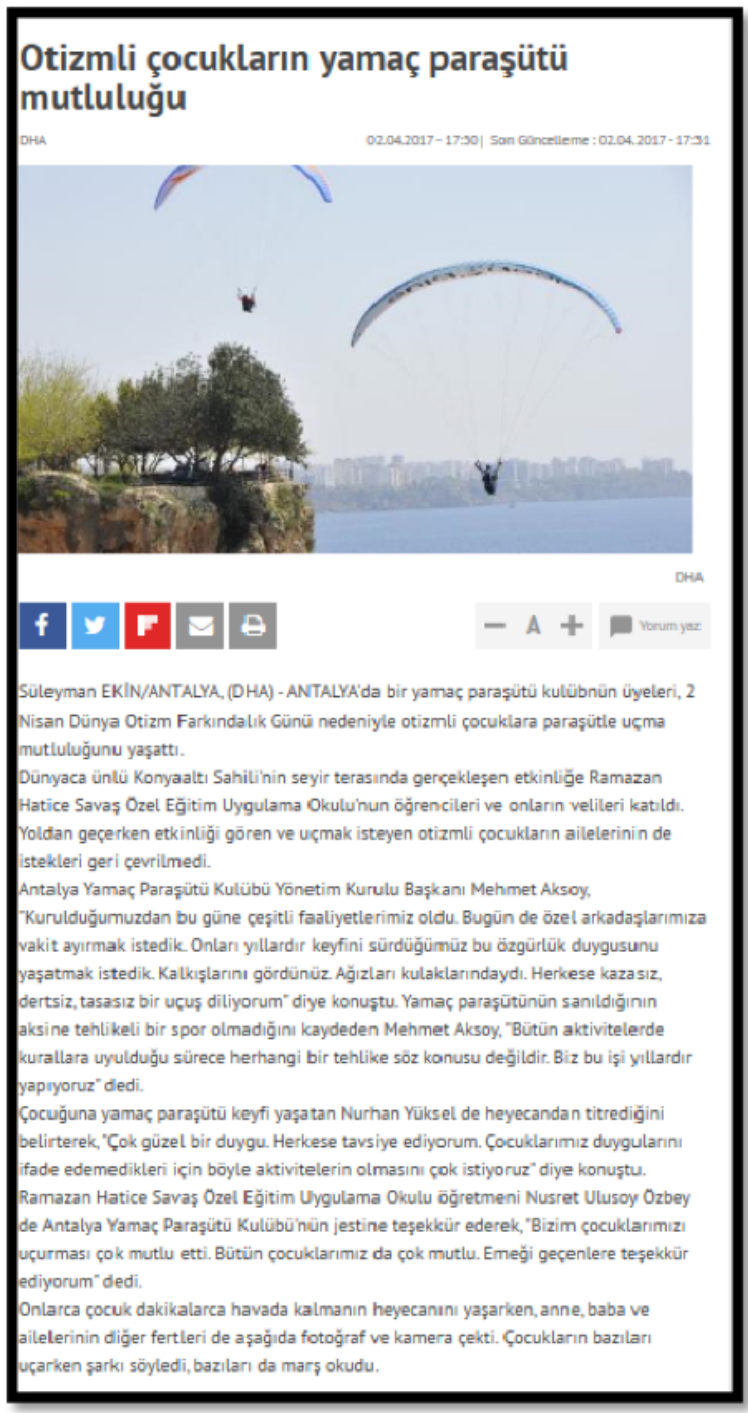

Görsel 2. Sosyal katılımla ilgili haber örneği.

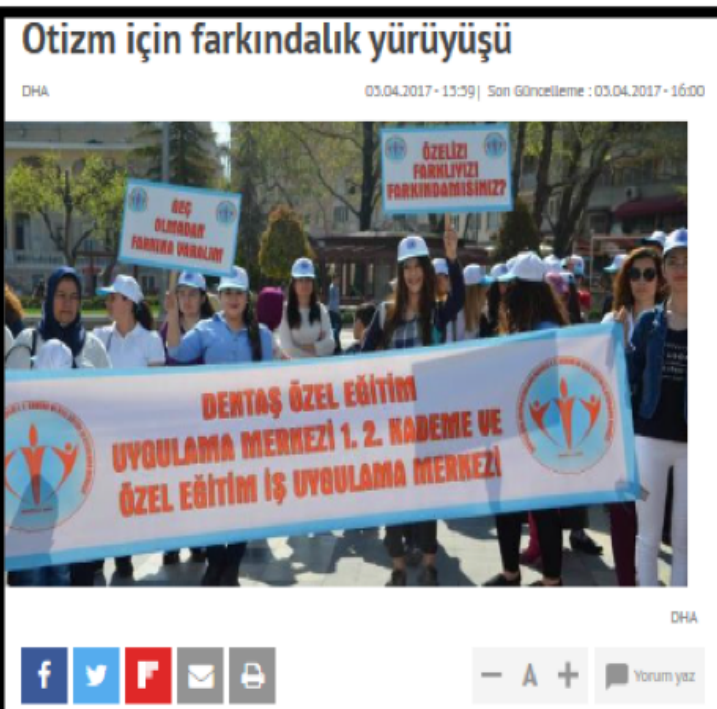

DENIZLl Otistik Çocuklanı Eğitim Merkezi'hin 2 Nisan Dünya Otizim Farkındalık Günühnde gerçekleștirdiği etkinlikle, özel çocuklar aileleriyle birlikte kortej yürüyüșü yaparak farkındalık olușturdu.

Otistik Çocuklan Eğitim Merkezi he kardeș okulların da destek verdiği etkinlikte otistik çccuklar aileleri, oğrenciler ve ögretmenleriyle Valilik önünden Büyükşehir Belediyesi önüne kadar kortej eşliğinde yürüdū. Ardından otistik çocuklardan oluşan mehter takımı konser verdi.

Otistik Çocuklan Eğitim Merkezi Müdürü Mustafa Söylemez, otizmin genellikle hayatın ilk 2-5 ylu içerisinde belirti veren, doğuștan gelen, beynin ve sinir sisteminin farklı yapısından ya da işleyişinden kaynaklandığı kabul edilen karmaşıkik, nörolojik tabanlı bir rahatsızık olduğunu söyledi. Söylemez, otizmin bilinen tek tedavisi erken tanı ile sürekli özel eğitim olduğunu belirterek, "Otizmli bireylerin topluma kazandırılmasında bugün için kabul edilmiş en önemli yōntem olan erken yaşta verilmeye başlanan bireyselleştirilmiş özel eğitim alan otizmli çocukların sosyal yönlerinin geliştiği, iletişim becerilerinin arttığı ve takıntılı davranışlarının azaldı̆ı bilinmektedir. Sevgi, sabır ve anlayıșla sürdürülen eğitimlerle desteklenen otizmli çocuklar, akranlarının sahip oldukları becerileri edinerek toplumda yerlerini alabilir. Bu konuda özellikle ailelere büyük sorumluluk düșüyor" dedi.

Görsel 3. Bilinçlendirme / farkındalıkla ilgili haber örneği. 


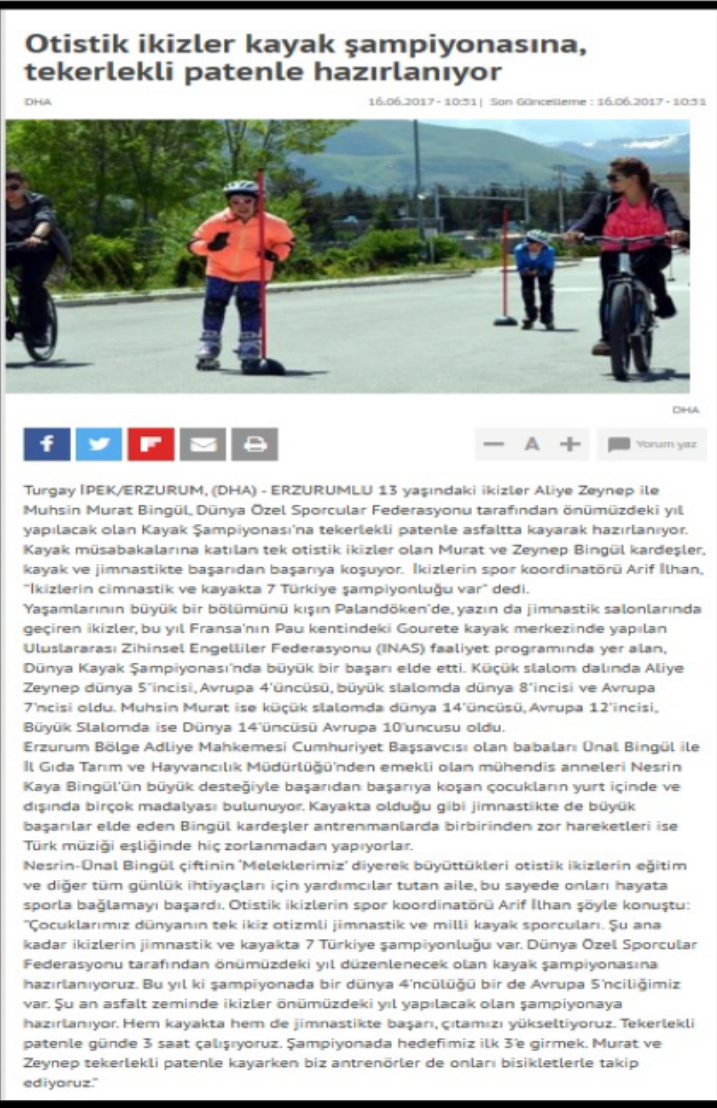

Görsel 4. Spor/sanatla ilgili haber örneği



Görsel 5. Sağlıkla ilgili haber örneği.

\section{TARTIŞMA}

Otizm ile ilgili haberlerin basılı medyada nasıl temsil edildiğini ortaya koymak amacıyla yaptığımız araştırmada, yaklaşık olarak 45 habere rastlanmış olması otizm hakkındaki haberlerin basılı medyada çok fazla yer almadığını göstermektedir.

Altuntaş ve ark (2015) yapmış oldukları çalışmada, bir yıl içinde risk altındaki çocuklarla ilgili çıkan toplam haber sayısının gazetelerde yayınlanan genel haber sayısına göre daha az olduğunu tespit etmiştir. Çalışmamızda, benzer şekilde otizm hakkında çıkan haber sayısının da çok az olduğu saptanmıştır.

Jones ve Harwood (2009) medyada otizm hakkında olumsuz içeriklerin yer aldığını belirtmektedir. Buna karşın; Türkmen, Kalpaklı ve Sevinç (2015) medyanın halk üzerine olan etkisinin olumlu yönde kullanılmasının halkın daha bilinçli olmasına yardımcı olacağını belirtmektedir. Bu nedenle, otizm hakkında olumlu içeriklere sahip haberlerin artırılmasının toplumun bilinçlenmesi için önemli olduğu söylenebilir.

Otizm Spektrum Bozukluğu Olan Bireylere Yönelik Ulusal Eylem Planı'nda, altı öncelikli alandan birisi olan "Eğitsel Değerlendirme, Özel Eğitim, Destek Eğitim Ve Rehabilitasyon Hizmetlerinin Geliştirilmesi" başlığı altında "OSB olan bireylerin 
ayrımcılığa uğramadan bütünleştirilmiş ortamlarda eğitim görmelerinin sağlanması ile eğitsel değerlendirilmeleri, özel eğitim, meslekî eğitim, destek eğitim ve rehabilitasyon hizmetlerinin geliştirilmesi" öncelik olarak verilmektedir. Çalışmamız sonucunda, OSB'li bireylerin eğitimi ile ilgili haberler incelendiğinde hippoterapi, eğitim merkezleri ve cep telefonu uygulamalarından bahsedildiği tespit edildi. Diğer taraftan, çalışmamızda haberlerde sağlıkla ilgili OSB'li çocuklar için ağız ve diş sağlığı, duyu bütünleme tedavisi, GAPS diyeti gibi tedavi yöntemlerine değinildiği tespit edildi (Bahçetepe, 2017a; Özgenç, 2017). Buna karşın, bu haberler yeterli düzeyde değildi. Bu açıdan, Otizm Spektrum Bozukluğu Olan Bireylere Yönelik Ulusal Eylem Planı'nın "Eğitsel Değerlendirme, Özel Eğitim, Destek Eğitim Ve Rehabilitasyon Hizmetlerinin Geliştirilmesi” başlığı altında yetersiz kaldığı söylenebilir.

Çalışmamızda spor/sanatla ilgili otizmli çocukların güzel sanatlara olan ilgilerine vurgu yapılarak başarı göstermiş olan otizmli çocuklardan bahsedildiği görülmüştür. Otizm Spektrum Bozukluğu Olan Bireylere Yönelik Ulusal Eylem Planı'nda spor ve sanatla ilgili "OSB olan öğrencilerden uygun olanların güzel sanatlar ve spor liselerinde kaynaştırma uygulamasından yararlanmasının sağlanması, yetenek sınavları, OSB olan bireylerin özelliklerine uygun hale getirilmesi ve bu okulların müfredatları geliştirilmesi" ve "Çeşitli sanat ve spor dallarında yetenekli olan ve yükseköğrenim görebilecek OSB olan bireylerin yükseköğrenim kurumlarına kabulü konusunda tabi oldukları değerlendirme sistemine ilişkin yasal düzenlemeler yapılması" alınacak olan tedbirlerdendir. Ancak, haberlerde, OSB'li bireylerin güzel sanatlara olan ilgi ve başarılarının vurgulanmasına rağmen, bahsi geçen yasal düzenleme, yetenek sınavı ve müfredatlarla ilgili herhangi bir habere rastlanmamıştır.

Çalışmamızda, haberlerde sosyal katılımla ilgili otizmli çocukların ve/veya ailelerine yönelik paraşütle atlama, gezi, korunaklı iş yerlerinde çalışmalarına destek olma, OSB'li çocuklar için düzenlenen konserler gibi haberler bulunduğu tespit edildi. Otizm Spektrum Bozukluğu Olan Bireylere Yönelik Ulusal Eylem Planı'nda yer alan diğer bir öncelikli alan ise "Sosyal Hizmet, Sosyal Yardım Ve Toplumsal Yaşama Katılım"'dı. Ancak Eylem Planı'nda alınacak tedbirler içerisinde evde bakım hizmetleri ile ilgili tedbirlerden bahsedilmektedir. Canarslan (2014) anneleri, çocuklarının bakım sorumluluğundan belirli bir süre kurtarmak, sadece kendilerine ayırdıkları kaliteli zamanlar için fırsat yaratmak ve toplumsal yaşama katılımlarını sağlamak, yaşam kalitelerinin yükselmesini ve hayata daha olumlu bakmalarını sağlayabileceğini vurgulamaktadır. Bu nedenle, Otizm Spektrum Bozukluğu Olan Bireylere Yönelik Ulusal Eylem Planı'nda yer verilen evde bakım hizmetlerinin geliştirilmesi önemlidir. Ancak, bu konu ile ilgili haber sayısı ve bilgilendirmenin yetersiz olduğu görülmüştür.

Otizm Spektrum Bozukluğu Olan Bireylere Yönelik Ulusal Eylem Planı'nda öncelik alanlarından biri olan "Farkındalık Çalışmaları Ve Kurumlararası İşbirliği" kapsamında, "toplumun tüm kesimlerinin OSB konusunda farkındalık düzeyinin artııılması ile OSB olan bireylere yönelik sağlık, eğitim ve destek hizmetlerinin sürekliliğinin sağlanması için kurumlararası işbirliğinin güçlendirilmesi" amaçlanmaktadır. Çalışmamızda, bilinçlendirme /farkındalık ile ilgili otizmin ne olduğu, erken tanı ve tedavi hakkında aileleri bilgilendirme gibi toplumun otizm konusunda bilgilenmesini amaçlayan haberlerin yer aldığı tespit edildi. Bulgularımıza göre, haber sayısının niceliksel olarak az olmasına karşın, toplumun bilgilenmesi açısından önemli olduğu düşünülmektedir.

Sonuç olarak, Otizm Spektrum Bozukluğu Olan Bireylere Yönelik Ulusal Eylem Planı'nın ardından medyadaki OSB'li çocuklarla ilgili yapılan haberlerin incelendiği çalışmamızda haberlerin eğitimle, bilinçlendirme/farkındalıkla, sosyal katıımla, spor/sanat ve sağlıkla ilgili olduğu ve niceliksel olarak yetersiz kaldığı tespit edilmiştir. 2016-2019 yılları içerisinde yürürlükte olacak olan Otizm Spektrum Bozukluğu Olan Bireylere Yönelik Ulusal Eylem Planı'na göre medyanın daha etkin ve bilinçli kullanılmasının önemli olduğu düşünülmektedir.

\section{Kaynaklar}

Altuntaş, O., \& Altınova, H. H. (2015). Türkiye'de risk altındaki çocukların ana akım basında temsili. Ergoterapi ve Rehabilitasyon Dergisi, 3(2), 59-69.

Amerikan Psikiyatri Birliği (1995). Mental Bozuklukların Tanısal ve Sayımsal El Kitabı. (E Köroğlu, Çev.) Ankara: Hekimler Yayın Birliği.

Anonim. (2017a, 25 Şubat). Atı terapi şifa dağıtıyor. Cumhuriyet gazetesi. Erişim tarihi 22 Eylül 2019, http://www.cumhuriyet.com.tr/foto/foto_galeri/684891/1/A tli_terapi_sifa_dagitiyor.html

Anonim. (2017b, 3 Nisan). Otizm ve spor festivalinde buluştular. Hürriyet gazetesi. Erişim tarihi 22 Eylül 2019, http://www.hurriyet.com.tr/otizm-ve-spor-festivalindebulustular-40415962

Anonim. (2017c, 3 Nisan). Otizm için farkındalık yürüyüşü. 
Hürriyet gazetesi. Erişim tarihi 22 Eylül 2019, http://www.hurriyet.com.tr/otizm-icin-farkindalikyuruyusu-40415938

Anonim. (2017d, 7 Nisan). Nusaybin'de Otizm günü kutlaması. Hürriyet gazetesi. Erişim tarihi 22 Eylül 2019, http://www.hurriyet.com.tr/nusaybinde-otizm-gunukutlamasi-40420174

Anonim. (2017e, 19 Nisan). Otistik çocuklar deniz sevgisini mozaikle anlattı. Hürriyet gazetesi. Erişim tarihi 22 Eylü 2019, http://www.hurriyet.com.tr/otistik-cocuklar-denizsevgisini-mozaikle-anlat-40431415

Anonim. (2017f, 16 Haziran). Üniversiteden mezun olan otistik Doruk, ailesinin gururu. Hürriyet gazetesi. Erişim tarihi 22 Eylül 2019, http://www.hurriyet.com.tr/universitedenmezun-olan-otistik-doruk-ailesin-40491965

Anonim. (2017g, 30 Haziran). Beykoz'un Mozart'ı otizml Yunus Yazar'ın konservatuvar hayali gerçek oldu. Cumhuriyet gazetesi. Erişim tarihi 22 Eylül 2019, http://www.cumhuriyet.com.tr/haber/turkiye/771394/Beyk oz_un_Mozart_i_otizmli_Yunus_Yazar_in_konservatuvar _hayali_gercek_oldu.html\#

Anonim. (2017h, 30 Kasım). MEB'den otizmli çocuklara özel program. Hürriyet gazetesi. Erişim tarihi 22 Eylül 2019 , http://www.hurriyet.com.tr/egitim/mebden-otizmlicocuklara-ozel-program-40663461

Anonim. (2017ı, 26 Aralık). Otizmli çocukları konuşturan 'Tolkido' Arıkovanı'nda. Hürriyet gazetesi. Erişim tarihi 22 Eylül 2019, http://www.hurriyet.com.tr/teknoloji/otizmlicocuklari-konusturan-tolkido-arikovaninda-40690243

Anonim. (2018, 6 Şubat). Otizmli çocuklara özel eğitim merkezi. Hürriyet gazetesi. Erişim tarihi 22 Eylül 2019, http://www.hurriyet.com.tr/otizmli-cocuklara-ozel-egitimmerkezi-40733009

Arman, A. (2018, 7 Şubat). Otizmli kardeşi için platform yaratt tüm dünyadan ödül yağdı!. Hürriyet gazetesi. Erişim tarihi 22 Eylül 2019, http://www.hurriyet.com.tr/yazarlar/aysearman/otizmli-kardesi-icin-platform-yaratti-tumdunyadan-odul-yagdi-40733645

Atalay, F. (2016, 5 Aralık). Otizimli çocukları kaliteli eğitim bekliyor. Cumhuriyet gazetesi. Erişim tarihi 22 Eylül 2019, http://www.cumhuriyet.com.tr/haber/egitim/640717/Otizi mli_cocuklari_kaliteli_egitim_bekliyor.html

Atalay, F. (2017, 2 Aralık). Farkında olmamak en büyük engel. Cumhuriyet gazetesi. Erişim tarihi 22 Eylül 2019 http://www.cumhuriyet.com.tr/haber/turkiye/878559/Farki nda_olmamak_en_buyuk_engel.html\#

Aydın, D., \& Özgen, Z. E. (2018). Çocuklarda otizm spektrum bozukluğu ve erken tanılamada hemşirenin rolü. Gümüşhane Üniversitesi Sağlık Bilimleri Dergisi, 7(3), 93101.

Bahçetepe, S. (2017a, 24 Ekim). Otizmle yaşamay kolaylaştııın. Cumhuriyet gazetesi. Erişim tarihi 22 Eylül 2019,

http://www.cumhuriyet.com.tr/haber/saglik/851310/Otizml e_yasamayi_kolaylastirin.html\#

Bahçetepe, S. (2017b, 19 Kasım). Otizmli çocuklara bakışınızı değiştirin. Cumhuriyet gazetesi. Erişim tarihi 22 Eylül 2019,

http://www.cumhuriyet.com.tr/haber/saglik/869533/Otizml i_cocuklara_bakisinizi_degistirin.html\#

Bogdan, R.C., Biklen, S.K. (1998). Qualitative research in education: An introduction to theory and methods (3rd ed.). Needham Heights, MA: Allyn \& Bacon.
Boyd-Barrett, O., \& Braham, P. (2013). Media, knowledge and power. New York, NY: Routledge.

Canarslan, H. (2014). Engelli çocuğa sahip ailelerin yaşam kalitesinin incelenmesi (Yüksek Lisans Tezi). Trakya Üniversitesi Sosyal Bilimler Enstitüsü, Edirne.

Cermak, S. A., Curtin, C., \& Bandini, L. G. (2010). Food selectivity and sensory sensitivity in children with autism spectrum disorders. J Acad Nutr Diet, 110(2), 238-246. https://doi.org/10.1016/j.jada.2009.10.032

Dörtkardeş, İ. (2017, 2 Nisan). Üniversitedeki hipoterapi projesinin ilk 'özel' öğrencileri. Hürriyet gazetesi. Erişim

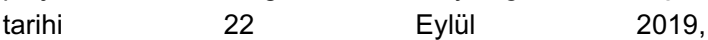
http://www.hurriyet.com.tr/universitedeki-hipoterapiprojesinin-ilk-oze-40414511

Ekin, S. (2017, 2 Nisan). Otizmli çocukların yamaç paraşütü mutluluğu. Hürriyet gazetesi. Erişim tarihi 22 Eylül 2019, http://www.hurriyet.com.tr/otizmli-cocuklarin-yamacparasutu-mutlulugu-40414870

Fahlvik-Planefeldt, C., \& Herrstrom, P. (2001). Dental care of autistic children within the non-specialized Public Dental Service. Swed Dent J, 25(3), 113-118.

İpek, T. (2017, 16 Haziran). Otistik ikizler kayak şampiyonasına, tekerlekli patenle hazırlanıyor. Hürriyet gazetesi. Erişim tarihi 22 Eylül 2019, http://www.hurriyet.com.tr/otistik-ikizler-kayaksampiyonasina-tekerlekli-40491874

Jones, S. C., \& Harwood, V. (2009). Representations of autism in Australian print media. Disabil Soc, 24(1), 5-18. https://doi.org/10.1080/09687590802535345

Köse, S., Özbaran, B., Yazgan, Y., Baytunca, M. B., Bildik, T., Erermiş, S., \& et al. (2017). 6-18 yaş aralığındaki çocuklarda Otizm Spektrum Tarama Ölçeği'nin Türkçe uyarlamasının psikometrik özellikleri. Turk Psikiyatri Derg, 28(4), 1-9. http://doi.org/10.5080/u14903

Kumanovalı, Ö. (2017, 9 Ekim). Otizm sendromlu çocuklar için anaokulu tasarlandı. Hürriyet gazetesi. Erişim tarihi 22 Eylül 2019, http://www.hurriyet.com.tr/otizmsendromlucocuklar-icin-anaokulu-tasarlan-40604394

Lee, L. C., Harrington, R. A., Louie, B. B., \& Newschaffer, C. J. (2008). Children with autism: Quality of life and parental concerns. J Autism Dev Disord, 38(6), 1147-1160. https://doi.org/10.1007/s10803-007-0491-0

Orsmond, G. I., Shattuck, P. T., Cooper, B. P., Sterzing, P. R., \& Anderson, K. A. (2013). Social participation among young adults with an autism spectrum disorder. J Autism Dev Disord, 43(11), 2710-2719. https://doi.org/10.1007/s10803-013-1833-8

Yüksek Planlama Kurulu. (2016). Otizm spektrum bozukluğu olan bireylere yönelik ulusal eylem planı. T.C. Resmi Gazete, 29907, 3 Aralık 2016.

Öndeş, Ö. (2018, 16 Ocak). İstanbul'da 9 bin çocuk otizm taramasından geçti. Hürriyet gazetesi. Erişim tarihi 22 Eylül 2019, http://www.hurriyet.com.tr/egitim/istanbulda9-bin-cocuk-otizm-taramasindan-gecti-40711609

Özbalı, H. (2017, 21 Mayıs). Otistik okulda mezuniyet ve karne şenliği. Hürriyet gazetesi. Erişim tarihi 22 Eylül 2019, http://www.hurriyet.com.tr/otistik-okulda-mezuniyetvekarne-senligi-40464706

Özel, B. (2017, 11 Temmuz). Engelli hastalarda diş tedavisinde genel anestezi ile çözüm. Hürriyet gazetesi. Erişim tarihi 22 Eylül 2019, http://www.hurriyet.com.tr/engellihastalarda-dis-tedavisinde-genel-aneste-40516186

Özgenç, M. (2017, 7 Nisan). Otizme karşı GAPS diyeti. 
Hürriyet gazetesi. Erişim tarihi 22 Eylül 2019, http://www.hurriyet.com.tr/otizme-karsi-gaps-diyeti40420343

Türkmen, A., Kalpaklı, F., \& Sevinç, İ. (2015). Benim adım khan filmi: Otizmin medyadaki yansıması. Sosyoloji Dergisi, 3(30), 381-395.

Yıldız, M. K. (2016, 3 Aralık). Aldığı yoğun eğitimle, 2 yılda otizmi yenip ilkokula başladı. Hürriyet gazetesi. Erişim tarihi $22 \quad$ Eylül 2019, http://www.hurriyet.com.tr/aldigiyogun-egitimle-2-yildaotizmi-yenip-ilk-40295550

Yosunkaya, E. (2013). Otizm etyolojisinde genetik ve güncel perspektif. Istanbul Tıp Fakültesi Dergisi, 76(4), 84-88. 